have combined these various characteristics. Mr. Lidtke's evidence and reasoning on this point are welcome.

While Mr. Lidtke's paper delivered rather more than it had promised at the outset, the opposite holds for "Social Democratic Organizations and the Anti-Nazi Underground" by William S. Allen. The comparison detracts in no way from Mr. Allen's manifest talent as historian and stylist, but rather it reflects the Socialists' own failures. The Socialists ruled out from the start the only conceivably effective means of resistance, i.e., assassinating Hitler, because their Marxian outlook held such individual terror a waste of effort. They considered armed resistance only to reject it out of hand. For about two years, they maintained an astonishingly well-circulated clandestine press, but to what purpose? When the Gestapo finally broke this up, the Socialists decided, logically enough, that the effort was simply not worth the risk. They sharply curtailed it, and until the end of the war, they were able simply to maintain some sort of organization in being, reconstituting their party immediately upon the war's end.

In the final analysis, then, here was a case where some sort of resistance, at least an inward resistance, grew out of an existing organization rather than the other way around. The activities engaged in were possible because of the close ties of trust and comradeship built up over the years before 1933. The only achievement was to keep the Party intact.

Both commentators, Professors Charles K. Warriner and Morris Janowitz, are sociologists. In particular, Mr. Warriner found Mr. Lidtke's work in close agreement with his own findings on voluntary associations (square dance groups in Missouri). Such evaluations are useful since historians have been criticized of late for dabbling in social science without understanding the subject area and techniques.

\author{
Donald B. Pryce \\ The University of South Dakota
}

\title{
SECOND CONFERENCE OF THE WESTERN SOCIETY FOR FRENCH HISTORY
}

There were several papers among those presented at this meeting (November 21-23, 1974, in San Francisco) which are of special interest to members of the study group. I will briefly discuss those papers I heard in person and will also list other papers that I was unable to attend.

In a session on Women in France from the 17th to the 19th Century, Marilyn Boxer (Women's Studies, San Diego State University) presented a paper entitled "Foyer or Factory: Working Class Women in 19th Century France." Ms. Boxer's paper dealt with the contlict between Marxian socialistfeminist ideology and the realities of working-class tradition and life patterns as expressed in French socialist congresses between 1866 and the first World War. She underscored the strength of the Proudhonian tradition among French workers concerning woman's place in the home, giving pithy examples of the hostility exhibited by articulate workingmen to the very notion of women in the 
industrial labor force. She then presented glimpses of the debate that ensued as Marxian concepts confronted those of Proudhon in the congresses of the First International and subsequently made their way into French socialist circles during the 1880's. She argued that not only ideology, but the economics of production and population as well, militated against any breakdown of the Proudhonian view among French workers and that the socialist groups who desired their support were obliged to face this fact. Since it proved impossible to push women back into the home (too many of them were unmarried), other political solutions were sought. The socialist groups finally concentrated on pressing demands for protective-restrictive legislation as a means of dealing with the working woman, despite the protests of French feminists and many socialist and working women alike. As of 1914, Boxer concluded, the hostility of the French worker to women in the work force was still very much a fact of life.

As a commentator for this session, I was struck by two points in Ms. Boxer's presentation: 1) that the milieu in which this debate was taking place was still one dominated by the atelier, the workshop of the skilled artisan, not by factory labor of the more advanced industrial type. This situation has particular ramifications because of the artisan's equivocal relationship to the newer machines, which made women into competitors and, economically speaking, into threats. Additionally, 2) the workers' viewpoint on women's place in the foyer appears to be, throughout this period, virtually indistinguishable from that of the bulk of the middle and petite bourgeoisie. This latter point raises a whole series of sociological questions concerning the relationship of the French artisinal worker to his social superiors and to his less-skilled inferiors in matters of familial values and organization, and concerning the ways in which these relationships may have changed over time as "modernization" proceeded.

A second paper of considerable interest was given by Evelyn Ackerman (Lehman College, CUNY) during a session on Social Problems in the 19th Century. Her topic was "The Social and Economic Development of Bonnières-sur-Seine in the Nineteenth Century." The village studied by Ackerman presents an exception to the general picture of rural decline and stagnation that supposedly typified small French towns and villages in this century; instead, this village, just 43 miles from Paris, entered a phase of moderate industrial development, due first to the building of the Paris-Rouen railroad, then to the ambition of a young entrepreneur named Michaux who founded a series of small industries in the town. The village population increased from 725 to 1231 between 1817 and 1896, and its social composition altered considerably, due to the arrival and settlement of a new commercial and professional class during the 1830's and 40's, and to the influx of workers from Brittany in the subsequent decades.

What is striking, from the standpoint of labor history, is that in each phase of development, workers were imported into Bonnières-sur-Seine. For the railroad, 10,000 transient English workers arrived in the vicinity; for the Michaux enterprises, a large contingent of Bretons settled there: later. when one of the factories changed hands, there was a settlement of Belgians as well. As Ackerman points out, however, the remarkable thing is that those newly-imported workers who did settle in Bonnieres hardly disturbed the social balance of the village. They kept to themselves and did not threaten the existing population, either socially or economically. Employment opportunities were 
always available, so conflict never arose over whom should be hired; housing, although never satisfactory, did not present an acute problem. In sum, the slow yet steady pace of change appears to have made it possible to avoid the polarization and social conflict that characterized other industrializing villages closer to Paris, such as Argenteuil, Bezons, or Saint-Denis.

The session commentator raised the intriguing question of whether the price of social peace in Bonnières was the ostracism of the Bretons and, later, the Belgians.

The third paper I attended was "The Political Origins of French Revolutionary Syndicalism" by Bernard Moss (University of Southern California), during a session devoted to The Political Consequencess of French Social Problems in the 19th Century. Moss argued that the workers' disposition toward revolutionary syndicalism was not influenced by the theories of intellectuals, but can best be studied through looking at its organization, which was federalist. As a political tendency, it was reinforced in the 80's and 90's by the opposition of its partisans, led by Allemane, to the "possibilist" tendency represented by Brousse. This opposition was exemplified by the attempt, in the early 1890 's. by the Allemanists to capture control of the bourses de travail, and later by their role in founding the Confédération générale du travail.

Other papers of interest, most of which dealt with earlier periods, included: James Friguglietti (Case Western Reserve), "The People and the Terror: History Seen From Below;" Cissie Fairchilds (University of California, San Diego), "The Condition of the Poor during the Revolution: A Debate;" and Emily Coleman, (University of Pittsburgh), "Peasant Society and Social Change in the 9th Century."

The Proceedings of this meeting will be published later in the year. Those interested in obtaining a personal copy or in ordering one for their institution's library should write to Professor Brison Gooch, Dept. of History, Texas A \& M University, College Station, Texas 77843.

\section{Karen M. Offen}

\section{BEBEL AND SOCIALISM}

This session at last fall's Southern Historical Association meeting in Dallas examined the formative years of August Bebel, the ideological influences that helped shape his thinking, and his responses to concrete political issues, in an attempt to understand his role in the development of the German Socialist Party and German socialism. The viewpoints expressed in the papers and those of the commentator were in conflict regarding several issues.

Professor Neitzel in "The Evolution of August Bebel's Social-Political Philosophy, 1864-1871" described Bebel's carly understanding of Marxism as relatively unsophisticated and partially derived irom unusual sources such as St. Ambrose. Early critics attacked his brand of "socialism" for being 